\title{
Recruitment, Retention and Exit from Union Membership. An Analysis of Member Flows in Swiss Union Locals
}

\author{
Daniel Oesch
}

\begin{abstract}
This article enquires into the causes of union growth and decline by analysing flows in and out of membership at the level of 70 Swiss union locals over 2006-2008. Gross flows in union membership are much larger than the resulting net changes: annual membership turnover of 10 per cent is a surprisingly constant feature across unions. Net changes in membership are primarily determined by inflows: successful and languishing union locals differ in their entry rates, whereas exit rates are similar. Variance in union locals' entry rates is not usefully explained by the labour market context, but by differences in union strategy.
\end{abstract}

\section{Introduction}

Trade unions play an essential role in determining the level of wage inequality or welfare state spending in Western European economies. In doing so, unions draw their influence and legitimacy, to a large extent, from their membership base. Growth and decline in union membership is thus not only consequential for unions themselves, but also affects countries' pattern of economic development and social cohesion. Accordingly, this article enquires into determinants of unions' success and failure in increasing their membership. In this undertaking, we diverge in two aspects from the bulk of earlier research on union growth and decline.

First, we select a different unit of analysis: there is an abundance of empirical enquiries into both micro- and macro-determinants of union growth in Western Europe. While micro-level research typically uses individual-level surveys and enquires into members' characteristics and motivations to join a union (e.g. Visser 2002; Waddington and Whitston 1997), macro-level research analyses union density on a country level and tries to explain 
variation with institutions, employment composition across sectors or the business cycle (e.g. Checchi and Visser 2005; Western 1995). With a few notable exceptions (Hancké 1993; Undy et al. 1981), a third level of analysis has received surprisingly little attention: the meso-level of the union local the place where recruitment and retention activities take place and where members are actually organized.

From a methodological point of view, the local union may well offer a more useful perspective to explain variation in union membership. The idea is that workers make their decision to join a union on the basis of their experience at the workplace — depending on how easy the access is to a local union and how well the local union deals with their grievances and provides them with services. Union locals are thus the primary recruitment centres (Hancké 1993: 596). At the same time, union locals differ significantly in their ability to recruit and retain members - depending on their strategic choices and organizational priorities. An illustration is provided by Undy et al.'s (1981) large British study, which shows strong variation in membership evolution between unions of the same sector as well as between union locals pertaining to the same union. These findings point to the crucial importance of local union leaderships. By focusing on the union local, this article thus adopts a perspective of union density where actors' choices matter (Baccaro et al. 2003). The relevance of strategic choice is widely acknowledged in research into political parties' fortune (e.g. Kitschelt 1994; Scharpf 1991). In contrast, union growth and decline is still commonly explained with the sole reference to institutions and economic conditions, whereas the actors themselves - unions - are often treated as secondary and their strategic choices largely deemed irrelevant (yet for exceptions see Frege and Kelly 2004; Milkman and Voss 2004).

Second, we partially diverge from earlier research with respect to the dependent variable. The literature on union membership typically focuses on annual net growth or decline in membership figures. However, annual net flows hide interesting dynamics of gross flows, that is entries into and exits out of union membership. Since duration of union membership is on average only a few years (Vaona 2008; Visser 2002), there is constant turnover of union members. Hence, even for stagnating membership figures, unions need to renew every year a substantial share of their membership in order to compensate for outflows. In other words, for unions 'it takes all the running you can do to keep in the same place' (Freeman 1988: 73). Accordingly, we focus on gross flows in and out of union locals to get a better understanding of net change in union membership.

We do so for Switzerland, a country where the union movement has adopted a type of industrial unionism and sectoral bargaining similar to that of Germany and the Netherlands, but where the decentralized political system affords local unions with greater autonomy. Yet as we will show below, the size of union entry and exit rates are surprisingly similar across West European countries. We thus probably deal here with mechanisms that are not specific to Switzerland. Our analysis is based on tailor-made register 
data stemming from 70 Swiss union locals, for which membership movements are observed over the three-year period 2006-2008. Union locals are either part of Unia, Switzerland's by far largest private sector union (56 union locals) or vpod, one of Switzerland's largest public sector unions (14 union locals).

Our findings suggest that changes in union membership are primarily determined by inflows. Successful union locals differ from languishing ones with respect to their entry rates, whereas exit rates show less variance. They are largely given by the labour market context and follow, to some extent, entry rates: a period of successful recruitment and large inflows goes along with higher outflows. Moreover, we observe large variance in union locals' in- and outflows that is neither accounted for by employment evolution nor by the demographic composition of the recruitment area. In contrast, inflows and outflows are strongly affected by differences of sector and region differences that appear largely attributable to union organization and strategy.

Our paper is organized as follows. Section 2 takes up a series of conceptual issues linked to flows in and out of union membership and compares two different strategies of union organization: a retention-centred and a recruitment-centred strategy. Section 3 discusses the institutional specificities of Swiss industrial relations, presents the data on union locals and shows how labour market controls are measured. Section 4 provides empirical evidence for the extent of flows in and out of union membership and analyzes their determinants. Section 5 examines the robustness of our results by doing a series of plausibility checks, before Section 6 concludes with the policy implications of our findings.

\section{Linking gross flows to net change in union membership}

In theory, growth in union membership can be obtained through two channels: through an increase in the entry rate while keeping the exit rate constant, or through a decrease in the exit rate for an unchanged entry rate. Trade unions are, like any other economic agent, confronted with opportunity costs, which constrain them to focus resources on some activities at the expense of others. Union resources primarily consist of the working time officials are able to allocate to different activities. In the presence of opportunity costs, two organizational strategies to increase membership can schematically be distinguished.

A first strategy consists in minimizing outflows, where unions try to reduce turnover by focusing their resources on the strengthening of member loyalty. This goal may be achieved through either an organizing or a servicing model. The organizing model implies the set-up of participatory opportunities and the organization of collective member activities in order to involve members into union affairs and thus foster union commitment. In contrast, the servicing model implies a stronger focus on the professional handling of members' 
individual queries and the continuous investment in selective rewards such as financial packages and further education offers, closely targeting members' needs. Particularly in servicing, great emphasis is put on 'customer-care' and hence the retention of already affiliated members.

A second strategy is less concerned about avoiding outflows, but more about maximizing inflows of new members. This is done by channelling resources into recruitment activities. Such a strategy implies that union representatives spend most of their time preparing recruitment campaigns and organizing new members at workplaces, at the expense of spending long hours in the office handling individual queries or organizing assemblies two activities that primarily cater to already affiliated members. Thus, the decision to spend time and resources on the recruitment of new members is likely to conflict with unions' responsibility to service existing members (Towers 1997: 96).

Already in the 1950, it was argued that a high degree of member turnover creates apathy and that, as a consequence, unions should redirect their energies from the task of getting new members to that of more effectively retaining those already affiliated (Goldstein 1952). Likewise, in recent years, studies on union organization have emphasized the importance of reducing membership turnover (Waddington 2006; Waddington and Kerr 1999). While a coherent retention strategy is clearly integral to union growth, our hypothesis is that trade unions have much greater influence on inflows than on outflows. In other terms, we expect differences in unions' membership evolution to be affected more strongly by the entry than the exit rate. The reason has to do with the determinants of inflows and outflows.

We expect inflows of new members into unions to be largely determined by parameters on which unions have a direct influence, most importantly a successful recruitment strategy: what sectors, firms and wage earner groups are targeted with what language and product? Where union locals are dynamic and invest most of their resources into the recruitment and defence of adequately targeted employee groups, we expect much higher inflows than where union locals mostly administer the status quo and invest very little effort into the recruitment of new members. In other words, where unions embark on a strategy of sustained recruitment and shift resources towards recruitment officers and organizing, they are more likely to achieve membership growth than where unions rely on passive recruitment and leave the affiliation of new members, by and large, to shop stewards or work councils (Kelly and Heery 1989: 197).

Unions' influence on outflows seems, in comparison, much smaller. Surveybased research from different countries suggests that the reasons why members leave a union are predominantly linked to changes in their job circumstances. Hence, three studies for Britain observe a surprisingly similar share of between 60 and 70 per cent of former union members who motivate their union exit with changes in their job situation: retirement, unemployment or moving to a job without a union (Gallie 1996: 170; Waddington 2006: 22; Waddington and Kerr 1999: 188). Likewise, a Dutch study finds the 
most important reason for leaving to be 'external events in the working career such as unemployment, childbirth and change of job or status (retirement)' (Visser 2002: 418). In the same vein, a survey in the Spanish region Catalonia reports that 60 per cent of union exits from Comisiones Obreras were motivated by reasons related to the job, and not the union (Jódar et al. 2009: 15). Finally, without giving a precise share, an Australian survey also finds the most common cause for exiting a union to be the movement from a 'union job' to a non-union workplace (Peetz 1998). These studies strongly suggest that job-related factors are paramount for member outflows, with only about 25-35 per cent of union members in Britain, 35 in Catalonia and 40 in the Netherlands having left because of dissatisfaction with union structure, organization or policy. ${ }^{1}$

More than half of total turnover thus seems due to changes in members' job environment, and hence to factors on which unions have little influence. There is not much unions can offer to workers moving to jobs in sectors outside their organizational area, to migrants returning to their home country or to women leaving the labour market after child-birth. The exit rate may thus vary less between dynamic and sluggish union locals than the entry rate, and hence to be less consequential for union growth and decline. This would imply that efforts concerning recruitment and inflows - and not activities targeting retention and outflows — distinguish growing from declining union locals. This argument is based on the expectation that inflows are largely a consequence of union strategy, whereas outflows are determined to a greater extent by structural factors. Four implications of this expectation can be tested empirically:

- We should observe greater variance in member inflows than outflows across union locals.

- Compared with outflows, inflows should account for more variance in net change of union membership.

- Factors linked to union organization and strategy should explain more variance in inflows than outflows.

- Factors linked to labour market evolution and employment structure should explain more variance in outflows than inflows.

\section{Study design: union structure, data and measures}

We analyse flows into and out of union locals for Switzerland. The Swiss union movement developed, comparable to German or Dutch unions, according to the principle of industrial unionism where both union organization and collective bargaining articulate around the economic sector. Yet unlike in Germany, but as in the Netherlands, organized labour in Switzerland remains divided into a secular and a religious union branch. Moreover, union density at 19 per cent and bargaining coverage at 50 per cent are low 
in international comparison (Oesch 2011: 87). As in Germany, Swiss unions continue to be dominated by semi-skilled male workers employed in manufacturing and construction, whereas service employees remain weakly organized. After decades of stability, Swiss unions have struggled with ongoing membership erosion since the early 1990s. A first reaction has involved the re-organization of the union structure through mergers. A second reaction has been a stronger emphasis on recruitment, coupled with an increased use of industrial disputes - a major change in Switzerland's traditionally highly cooperative system of industrial relations (Oesch 2011: 95). However, this study is not primarily about Swiss unionism, but about the mechanisms governing flows in and out of union membership - mechanisms that obey to a similar logic across West European countries, as will be shown below.

Our analysis focuses on two unions: the public-sector union vpod and the conglomerate private-sector union Unia. The result of a merger between four unions in 2002, Unia has 200,000 members and is by far Switzerland's largest union, accounting for about 30 per cent of total Swiss union membership and 50 per cent of membership within the main union confederation $S G B$ (Oesch 2011: 96). Unia is Switzerland's principal union in construction, manufacturing and private consumer services such as retail trade, hotels and restaurants. In comparison, the public-sector union vpod $^{2}$ is much smaller with 35,000 members. Still, in Switzerland's organizationally fragmented public sector, it is one of the major unions, recruiting workers in health care, education, public administration and public transports.

Given Switzerland's cultural diversity, its political system is highly decentralized. Decentralization has also left its imprint on the union movement, where not only unions' sector organizations, but also their regional entities within a sector enjoy considerable autonomy. This leads us to our definition of the union local, a concept that can cover a variety of sometimes very different organizations across countries (Hancké 1993: 596). Here, a union local is defined as the functional unit that organizes workers of a given sector in a given region. In the case of Unia, a matrix organization gives large autonomy to 14 regions and the following four sectors: (i) the principal parts of the building trade, (ii) the secondary parts of the building trade (called artisanat thereafter), (iii) manufacturing and (iv) private services. By combining Unia's territorial and sectoral levels, we obtain the 56 organizational units corresponding to the concept of a union local. Examples of such union locals are 'principal parts of the building trade in Zurich', 'manufacturing in Geneva' or 'private services in Ticino'. This is the place where day-to-day activities of recruitment and retention are planned and executed under the direction of regional sector-leaders. For the smaller public-sector union vpod, union locals need only be differentiated according to the same 14 regions. Our database thus consists of 56 union locals pertaining to Unia and 14 union locals pertaining to vpod. ${ }^{3}$ Variation in union locals' gross membership are recorded annually over the three-year period 2006-2008, which provides us with 210 observations for member inflows and outflows (70 union locals observed for three consecutive years). These data on aggregate changes in 
union locals' membership have been tailor-made on the basis of raw data provided to us by Unia and vpod.

Alongside our key variable, gross flows based on unions' register data, we need to account for differences in union locals' labour market context. For this reason, we compute measures based on the individual-level data contained in the Swiss Labour Force Surveys (SAKE) 2005-2008. Providing large samples of between 51,835 (2005) and 47,930 (2008) individuals, SAKE is the standard data source to investigate employment change in Switzerland. We create measures for three different indicators of the labour market cycle: (i) the unemployment rate, (ii) change in the unemployment rate and (iii) employment growth/decline. The literature leads us to expect lower entry and higher exit rates in union locals where employment decreases and unemployment increases (Schnabel 2003: 22). In addition, we calculate workers' average job tenure in years. The idea is that member outflows (and possibly inflows) are higher in labour markets where, on average, employees' job tenure is low and turnover high. We further control for the share in the workforce of two groups with lower attachment to the job, and hence possibly to union membership: women and foreigners (Vaona 2008: 264). This is done by calculating women's and foreign workers' employment share in a given union local's recruitment area. Finally, we compute a measure for union density in order to control for a union local's market share - the proportion of the workforce in a given region's sector that is already organized. In- and outflows are likely to be lower in union locals where a large share of workers are already unionized (as, for instance, in the principal building trade of Jura or Ticino).

All these measures are computed for a target population that matches the organizational areas of Unia's and vpod's union locals as closely as possible. To give an example, we measure the unemployment rate (or average job tenure or union market share, etc.) for private consumer services in Geneva, for public services in Ticino or for manufacturing in Zurich. Although the principal (builders, masons, etc.) and secondary trades of building (plumbers, painters, electricians, etc.) are organized in different union locals in Unia, our SAKE surveys do not keep these subsectors of construction apart. Hence, the same labour market measures are used for union locals in these two sectors which does not seem problematic insofar as these two subsectors closely resemble each other with respect to the business cycle and employment composition. Table A1 in the Appendix section presents the descriptive statistics for these variables.

Alongside these labour market measures, we use qualitative knowledge to compute several dummy variables. A first dummy is created for large cities Basel, Geneva and Zurich — where unions may have lower organizational costs (Schnabel and Wagner 2005), but also more discontinuous membership. A second dummy variable distinguishes union locals in Latin cantons from union locals in German-speaking cantons: while the former may be more influenced by French and Italian social movement unionism, the latter are likely to be closer to Germany's social partnership model. A third and last 
dummy variable differentiates union locals facing competition from other labour organizations and union locals enjoying a quasi-monopoly in worker representation. Basically, Unia's union locals only face competition from other unions in the few predominantly catholic regions such as Central Switzerland, Fribourg, Ticino and Valais (from the social-christian union Syna), in Geneva (from the regional union Sit) and in the manufacturing sector in the German-speaking regions (from the white-collar union Angestellte Schweiz). As to vpod, all its 14 union locals are confronted with competing public-sector unions.

\section{Empirical evidence for flows in and out of union membership}

We begin our empirical analyses with a look at entry and exit rates of the two trade unions under study. Table 1 thus shows that gross flows in and out of union membership are much larger than the resulting net changes. vpod registers an annual outflow from their membership of 9-10 per cent and Unia of 12-13 per cent. These outflows imply that trade unions need to organize large numbers of new workers each year to keep membership figures even. In effect, newly recruited members amount each year to around 9 (vpod) to 11 per cent (Unia) of existing membership. While these inflow rates convey a sense of dynamism, they were not high enough to compensate for member outflows from Unia and vpod between 2006 and 2008, resulting in annual gaps of between -0.2 (vpod in 2008) and -2.0 percentage points (Unia in 2007).

To what extent are these flows, observed for two Swiss unions, representative for other trade unions in Western Europe? Several studies suggest that we deal here with a phenomenon that is very similar across countries. A Spanish study reports an entry rate of 14.5 per cent and an exit rate of 11.3 per cent for Comisiones Obreras in Catalonia in 2004 (Jódar et al. 2009: 1). In Britain's large public-sector union Unison, both the entry and exit rate over the 1990s stood at 12.5 per cent (Waddington and Kerr 1999: 185). Evidence from the Dutch CBS union survey over the 1970s and 1980s shows member movements to fluctuate between 6.1 and 12.4 per cent for annual entry rates and between 7.2 and 11.1 per cent for annual exit rates (Van Ours 1991: 11). Membership turnover of annually around 10 per cent thus seems a surprisingly constant feature of West European unions.

TABLE 1

Annual Entry and Exit Rates of Members In and Out of the Union (in \%)

\begin{tabular}{|c|c|c|c|c|c|c|}
\hline & \multicolumn{2}{|c|}{ Entry rate } & \multicolumn{2}{|c|}{ Exit rate } & \multicolumn{2}{|c|}{ Net change } \\
\hline & Unia & vpod & Unia & vpod & Unia & vpod \\
\hline 2006 & 11.0 & 8.7 & 12.5 & 10.3 & -1.5 & -1.6 \\
\hline 2007 & 11.0 & 9.0 & 13.0 & 9.3 & -2.0 & -0.3 \\
\hline 2008 & 11.2 & 9.0 & 12.6 & 9.1 & -1.3 & -0.2 \\
\hline
\end{tabular}

(C) Blackwell Publishing Ltd/London School of Economics 2011. 
We examine flows in greater detail by computing median and average entry and exit rates into and out of the 210 union locals in our sample, differentiated by sector (see Table 2). While the five sectors are very similar in terms of size - each counting between 35,000 and 50,000 members ${ }^{4}$ - they strongly differ with respect to turnover. By far the highest entry and exit rates can be observed for union locals of Unia's private service sector, mainly encompassing low-skilled workers in retail trade, hotels and restaurants. Half of the union locals organizing this sector achieved an annual entry rate of 17.4 per cent or more, while the median exit rate was 16.8 per cent. In contrast, the lowest gross flows apply to vpod's public services, which mainly comprise medium-skilled workers in health care, education, public administration and transports. In this sector, half of all union locals limited the annual exit rate to 8.9 per cent or less. At the same time, the median entry rate was much lower with 7.6 per cent.

How much do in- and outflows vary across unions locals? The standard deviations computed in Table 2 point towards two interesting results. First with respect to the sector, we find union locals to vary much less in terms of entry and exit rates within the principal trade of building and manufacturing than within private and public services. Although union locals in (lowskilled) private services have much higher entry and exit rates than those in (mid-skilled) public services, differences in flows between union locals are similarly large in these two sectors. In contrast, union locals have particularly low variance in their entry, and above all, exit rates in manufacturing. In this sector, we deal with a relatively homogeneous group of union locals that struggle with very low inflows of new members - inflows that are clearly insufficient to compensate for the outflows. Compared to the situation in manufacturing, union locals are much less homogeneous within artisanat, where the high standard deviation in entry rates suggests that thriving and struggling union locals coexist in this sector.

Second, we find union locals to vary more in their entry than their exit rates. For all union locals in our sample, the standard deviation was 5.6 percentage points for a mean entry rate of 11.9 per cent. In comparison, the standard deviation amounted to only 3.7 percentage points for a mean exit rate of 12.6 per cent. With the exception of public services, variance is at least

TABLE 2

Entry and Exit Rates Across Union Locals by Economic Sector, 2006-2008

\begin{tabular}{lrrrrrrrrr}
\hline & \multicolumn{3}{c}{ Entry rate } & & \multicolumn{3}{c}{ Exit rate } & $n$ \\
\cline { 2 - 3 } & Median & Mean & s.d. & & Median & Mean & s.d. & \\
\hline Primary building & 11.9 & 12.7 & 3.5 & & 12.6 & 12.8 & 2.3 & 42 \\
Artisanat & 12.1 & 13.1 & 4.9 & & 13.2 & 13.3 & 2.5 & 42 \\
Manufacturing & 7.0 & 7.2 & 2.8 & & 10.6 & 10.8 & 1.9 & 42 \\
Private services & 17.4 & 18.1 & 4.4 & & 16.8 & 16.7 & 2.7 & 42 \\
Public services & 7.6 & 8.6 & 4.3 & & 8.9 & 10.1 & 4.3 & 42 \\
All & 11.2 & 11.9 & 5.6 & & 12.4 & 12.7 & 3.7 & 210 \\
\hline
\end{tabular}

(C) Blackwell Publishing Ltd/London School of Economics 2011. 
50 per cent higher in inflows than outflows in all sectors. This result seems consistent with the argument that growing and declining union locals primarily differ in their capacity to recruit new members, while outflows are largely given by the economic context.

Do trade unions expand their membership primarily through high inflows (because of their attractivity in recruiting new members) or through low outflows (because of their capacity in retaining members)? We address this issue by plotting union locals' annual net change in membership against their annual entry and exit rates. The respective scatter plots - shown in Figures 1 and 2 - reveal that net change in membership correlates much more strongly with entry than exit rates. The Pearson's coefficient is $r=0.75$ for the correlation between entry rates and net change, as compared to only $r=-0.10$ for the correlation between exit rates and net change. Hence, there is a strongly positive relation between inflows and membership growth, but only an insignificant negative link between outflows and membership growth.

We analyse the impact of gross flows on net membership change with a regression model. Since our observations stem from 70 union locals measured over three consecutive years, we use a pooled time-series cross-section model and calculate robust OLS-regressions with Huber-White standard errors that correct for autocorrelation within union locals over consecutive years (Breen 2005; 131). Moreover, we integrate controls for the different years. Results are reported in Table 3 and show that only entry, but not exit rates, are significantly linked with union locals' net change in membership. Moreover, we account for much more variance in net change across union locals

FIGURE 1

The Relation between Annual Entry Rates and Net Change in Membership. N: 210;

Pearson's $r: 0.75$.

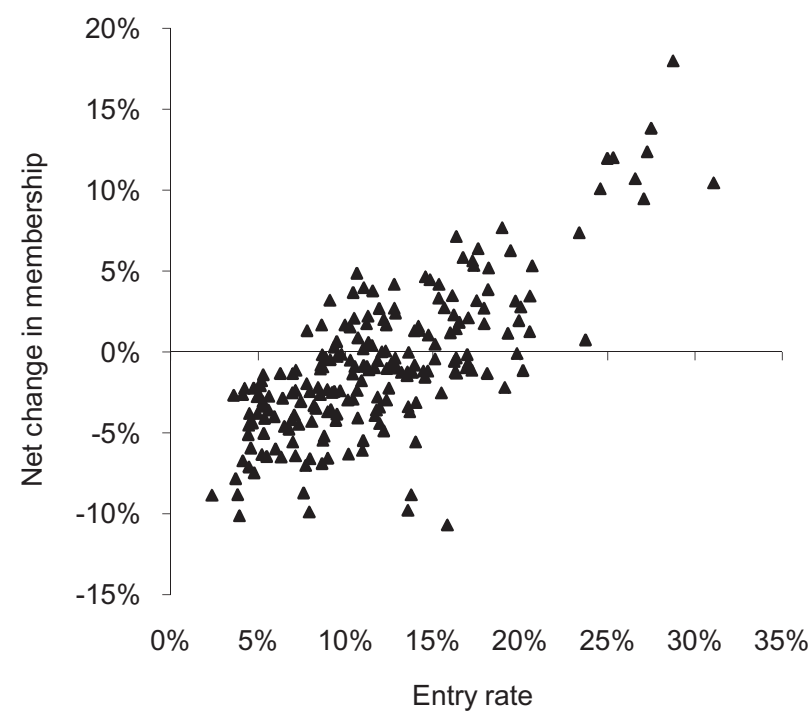

(C) Blackwell Publishing Ltd/London School of Economics 2011. 
FIGURE 2

The Relation between Annual Exit Rates and Net Change in Membership. N: 210; Pearson's $r:-0.10$.

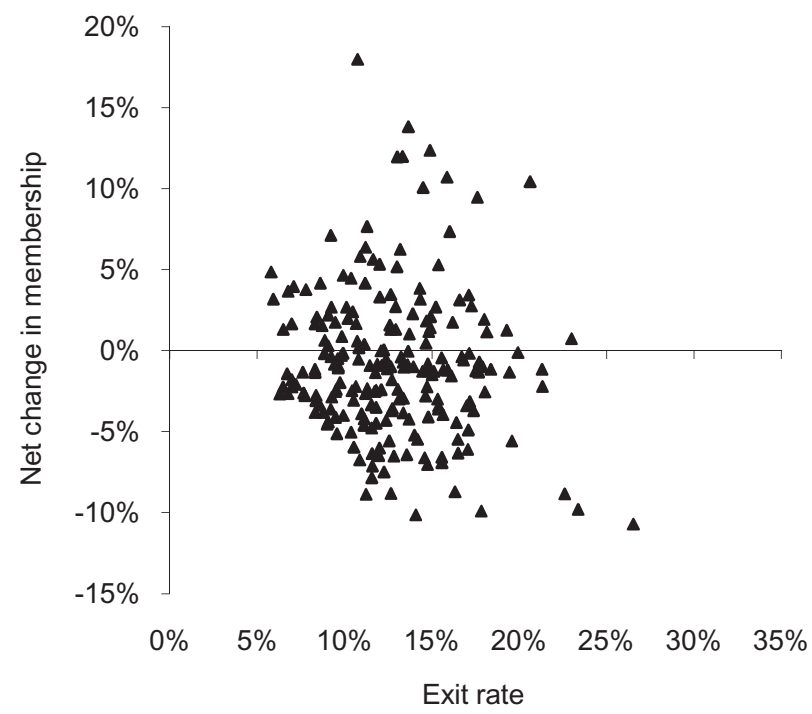

TABLE 3

Regression for the Determinants of Annual Net Change in Union Membership

\begin{tabular}{|c|c|c|c|c|}
\hline & \multicolumn{2}{|c|}{ Inflows on net change } & \multicolumn{2}{|c|}{ Outflows on net change } \\
\hline & Coef. & t-value & Coef. & $\mathrm{t}$-value \\
\hline Entry rates & $0.61 * * *$ & 10.59 & & \\
\hline Exit rates & & & -0.12 & -1.19 \\
\hline 2006 & 0.01 & 1.66 & $0.01^{* *}$ & 2.88 \\
\hline 2007 & -0.00 & -0.47 & 0.00 & 0.71 \\
\hline Constant & $-0.08 * * *$ & -11.15 & 0.00 & 0.05 \\
\hline$R^{2}$ & \multirow{2}{*}{\multicolumn{2}{|c|}{$\begin{array}{l}0.57 \\
210\end{array}$}} & \multicolumn{2}{|c|}{0.03} \\
\hline $\mathrm{N}$ observations & & & & \\
\hline
\end{tabular}

** Significant at the level $P=0.01 ; * * *$ Significant at the level $P=0.001$ (robust standard errors).

with entry than exit rates: entry rates and year dummies explain 57 per cent of variance in membership evolution as to only 3 per cent for exit rates and year dummies. These results thus indicate that the increase of a union local's entry rate by 1 percentage point leads to a net increase in union membership by about 0.61 percentage point. In contrast, differences in exit rates do not explain the variation in membership growth across union locals.

Having examined the link between flows and net change, we need to shed light on the determinants of in- and outflows themselves. The issue at stake is to know whether differences in flows between union locals are primarily due 


\section{British Journal of Industrial Relations}

to external variables of a given labour market context (which are mostly beyond union locals' influence) or to internal factors reflecting organizational differences between union locals. We address this issue by estimating two different regression models of in- and outflows.

A first model analyses the impact of external factors that potentially obstruct or, on the contrary, facilitate recruitment and retention of members: union locals' labour market environment in terms of unemployment, employment growth, union market share, workers' job tenure, the proportion of women and foreign workers in the recruitment area, large city or small town, Latin or German-speaking canton, presence or absence of a concurrent union. A second model only integrates two variables: sector and region dummies. We argue that these two variables capture internal aspects of organization and strategy: It is at the sectoral level that Unia and vpod define their organizational strategy and lead their negotiations over — often national, sometimes cantonal - collective agreements and pay increases (Mach and Oesch 2003). These strategies are then adapted and put to practise at the regional level, where recruitment activities and participatory forums are set up. A union local is thus exposed to both decisions taken on the sectoral and the regional level.

Table 4 shows the result of the model estimating the influence of the external labour market context on member in- and outflows. Consistent with expectations, these structural variables explain more variance in exit than entry rates. Although differences are small (34 and 27 per cent of variance explained, respectively), a union local's labour market context seems to affect

TABLE 4

External Determinants (Linked to the Labour Market Context) of Annual Entry and Exit Rates across Union Locals

\begin{tabular}{|c|c|c|c|c|}
\hline & \multicolumn{4}{|c|}{ Dependent variable } \\
\hline & \multicolumn{2}{|c|}{ Entry rate } & \multicolumn{2}{|c|}{ Exit rate } \\
\hline & Coef. & $\mathrm{t}$-value & Coef. & $\mathrm{t}$-value \\
\hline Unemployment rate & 0.39 & 1.72 & $0.48 * *$ & 3.31 \\
\hline Change in unemployment rate & -0.18 & -1.20 & -0.23 & -1.95 \\
\hline Change in employment & -0.03 & -0.79 & -0.02 & -0.53 \\
\hline Market share (union density) & $-0.12 *$ & -2.44 & $-0.11 * *$ & -3.53 \\
\hline Job tenure (in years) & $-0.01 * *$ & -3.58 & $-0.01 * *$ & -2.84 \\
\hline Share of women & -0.03 & -0.74 & -0.04 & -1.73 \\
\hline Share of foreigners & 0.11 & 1.33 & 0.04 & 0.81 \\
\hline Large city & -0.02 & -0.97 & 0.00 & 0.36 \\
\hline Latin canton & -0.00 & 0.28 & -0.00 & -0.42 \\
\hline Presence of competing union & $-0.03 * *$ & -2.72 & $-0.02 * * *$ & -3.78 \\
\hline 2006 & $0.01^{*}$ & 2.47 & -0.00 & -0.66 \\
\hline 2007 & 0.00 & 1.25 & 0.00 & 0.83 \\
\hline Constant & $0.22 * * *$ & 4.70 & $0.20 * * *$ & 8.18 \\
\hline$R^{2}$ & \multicolumn{2}{|c|}{0.27} & \multicolumn{2}{|c|}{0.34} \\
\hline $\mathrm{N}$ observations & \multicolumn{2}{|c|}{210} & \multicolumn{2}{|c|}{210} \\
\hline
\end{tabular}

* Significant at the level $P=0.05 ; * * \quad P=0.01 ; * * * \quad P=0.001$ (robust standard errors). 
exit rates more than entry rates. When looking at single variables, we find three contextual factors to be significantly linked to both entry and exit rates. First, the presence of a competing union slightly depresses inflows, but also leads to somewhat lower outflows. Hence, union locals confronted in their recruitment area with competing unions seem to struggle more to organize new workers, but once affiliated these workers show higher attachment. Second, where union locals already organize a large share of the workforce in their recruitment area, both in- and outflows are smaller. A large market share thus reduces the potential for new recruitment, but since it leads to stronger bargaining power and larger peer pressure, it is also conducive to membership stability. Third, longer average job tenure in a given region and sector is associated with lower in- and outflows. The result's interpretation is intuitive: where job tenure is on average short and hence job turnover high (as for example in restaurants and hotels), union locals need to recruit more workers in order to compensate for higher exit rates.

A variable that only seems to affect outflows, but not inflows, is unemployment. In union locals where the unemployment rate is higher, outflows are also higher. In contrast, annual changes in employment and unemployment are not significantly linked to in- or outflows. Not too much should be made of this result: the period under study is short and covers three homogenous years at the end of a broadly shared cyclical upswing, when employment was growing and unemployment falling country- and sector-wide. More interesting is the fact that a union local's in- and outflows are neither affected by the share of women and foreigners in its recruitment area, nor by its setting in a large city or a particular linguistic region. These contextual factors do not seem to explain why union locals' have grown or declined over the period under study.

Table 5 shows the results of the model capturing the effect of internal differences between union locals, linked to region and sector organization, on in- and outflows. Its explanatory power is almost twice as large as that of the model integrating the external labour market context. When looking at single variables, we find sectoral differences to have a particularly large effect on inflows. Holding years and regional differences constant, our model predicts an entry rate that is 6 percentage points lower in manufacturing and 5 percentage points higher in private services than in the reference category, artisanat. In comparison, the effects of sector on exit rates are only half as large. For exit rates, differences across regions seem to be more consequential. When taking Italian-speaking Ticino - the region with highest net growth in membership over 2006-2008 - as the benchmark, we find all other regions to have significantly higher annual exit rates, exceeding those of Ticino by $2-6$ percentage points. While Ticino also performs better than almost all regions in terms of inflows (the sole exception being Central Switzerland), differences are only statistically significant with respect to 4 of the 13 regions compared. The regressions in Tables 4 and 5 suggest that union growth and decline are more usefully explained by sector and region which are linked, we argue, to internal differences in union locals' strategy 


\section{British Journal of Industrial Relations}

TABLE 5

Internal Determinants (Linked to Union Organization) of Annual Entry and Exit Rates across Union Locals

\begin{tabular}{|c|c|c|c|c|}
\hline & & Depe & Iriable & \\
\hline & & & & \\
\hline & Coef. & $\mathrm{t}$-value & Coef. & $\mathrm{t}$-value \\
\hline Sector & & & & \\
\hline $\begin{array}{l}\text { Principal building } \\
\text { Artisanat (reference) }\end{array}$ & 0.00 & -0.35 & -0.01 & -0.77 \\
\hline Manufacturing & $-0.06 * * *$ & -4.71 & $-0.03 * * *$ & -4.71 \\
\hline Private services & $0.05 * * *$ & 4.44 & $0.03 * * *$ & 6.24 \\
\hline Public services & $-0.04 * *$ & -3.22 & $-0.03 * *$ & -3.47 \\
\hline Region & & & & \\
\hline Geneva & -0.03 & -1.33 & $0.04 * * *$ & 4.78 \\
\hline Vaud & -0.01 & -0.42 & $0.04 * *$ & 2.84 \\
\hline Valais & -0.03 & -1.38 & $0.02 * *$ & 2.85 \\
\hline Neuchatel & -0.03 & -1.82 & $0.03^{* * *}$ & 4.86 \\
\hline Larger Jura & $-0.04 *$ & -2.01 & $0.03 * * *$ & 4.15 \\
\hline Fribourg & -0.01 & -0.75 & $0.06^{* *}$ & 3.24 \\
\hline Ticino (reference) & & & & \\
\hline Larger Basel & -0.03 & -1.74 & $0.05 * * *$ & 5.21 \\
\hline Biel/Solothurn & $-0.04 *$ & -2.19 & $0.04 * *$ & 3.36 \\
\hline Berne & $-0.04 *$ & -2.28 & $0.02 * * *$ & 2.46 \\
\hline Aargau & $-0.05 * *$ & -2.73 & $0.04 * * *$ & 3.84 \\
\hline Central Switzerland & 0.02 & 0.56 & $0.03^{* * *}$ & 4.52 \\
\hline Zurich & -0.01 & -0.79 & $0.04 * * *$ & 4.49 \\
\hline Eastern Switzerland & -0.03 & -1.73 & $0.05^{* * *}$ & 8.95 \\
\hline 2006 & $0.01 * *$ & 2.77 & 0.00 & -0.15 \\
\hline 2007 & $0.01^{*}$ & 1.85 & 0.00 & 1.35 \\
\hline 2008 (reference) & & & & \\
\hline Constant & $0.15^{* * *}$ & 8.88 & 0.10 & 14.13 \\
\hline$R^{2}$ & & & & \\
\hline $\mathrm{N}$ observations & & & & \\
\hline
\end{tabular}

* Significant at the level $P=0.05$; ** $P=0.01$; ** $P=0.001$ (robust standard errors).

and organization — than by external differences in union locals' labour market environment.

\section{A plausibility check of the results}

Three questions arise with respect to these findings: First, is it plausible that union growth is mainly determined by inflows — and not by outflows? Second, why should entry rates be more consequential for union growth than exit rates? Third, can we interpret region and sector differences as differences of strategy rather than differences in union locals' labour market environment?

We discuss the first issue by comparing gross flows and net change of the ten most strongly growing and the ten most strongly declining union locals over the period 2006-2008. ${ }^{5}$ This comparison reveals that the three most and 
the three least dynamic union locals differ very little in their exit rates, but are separated by more than 20 percentage points with respect to their entry rates. This finding implies that exit rates are, to some extent, given by the labour market context: Union locals active in sectors with a convincing recruitment strategy (private services, artisanat) and set in regions with a cohesive union team (Ticino, Central Switzerland) overcompensate turnover in their membership with new affiliates. In contrast, union locals active in sectors without a clear recruitment strategy (manufacturing) and set in regions with a leadership problem and/or high rotation among union staff (Aargau, Eastern Switzerland) fail to achieve entry rates that are sufficient to make up for turnover in membership.

The key role played by entry rates is further highlighted by one of the few studies to enquire into trade union flows: In an analysis of union growth in the Netherlands, Jan Van Ours's (1991) finds the strong decline in union membership at the beginning of the 1980s and renewed growth after 1986 to be driven by fluctuations in the entries of new members. Contrary to expectations, the Dutch recession of the early 1980s did not lead to a higher exit rate among union members, but to a decrease in the entry rate of new workers. Between 1978-1979 and 1984-1985, the entry rate dropped from 10 to 6 per cent, whereas the exit rate remained stable at around 10 per cent (Van Ours 1991: 11).

This leads us to the second issue of why inflows should be more consequential for union growth than outflows. There are probably three main reasons: A large fraction of outflows are — unlike inflows — due to causes largely beyond the influence of unions, being related either to demographic (birth of a child, death, out-migration) or work-related changes (change of workplace, unemployment, retirement) (Jódar et al. 2009; Waddington 2006). In addition, there is an element of inertia in union membership. Once an individual has joined a union, there is a tendency to remain affiliated even if the original incentive for joining has disappeared (Elias 1996: 205). Hence, if a union local loses dynamism and begins to underperform, this lethargy will show quickly in a decline of inflows, whereas outflows are likely to react much more slowly. Finally, outflows are not independent from inflows. In fact, union locals that organize higher shares of new members are also likely — all other things being equal — to experience higher rates of outflows. This is due to the fact that median duration of union membership is short - five years in the Netherlands (Visser 2002: 418), four years among CGIL members of North-Eastern Italy (Vaona 2008: 264). Accordingly, the probability of leaving is by far highest among recent members. The tenuous relationship between unions and recently recruited members is also evident for Unia: 33 per cent of members who had joined the union in 2006 and 19 per cent who had done so in 2007 had left again in 2009.

The impact of inflows on outflows can be estimated in a regression where the dependent variable is the exit rate and the independent variable the entry rate, with control variables for year and sector. The result is shown in Table 6 and confirms that union locals in Switzerland with higher entry rates also 
TABLE 6

The Impact of Entry Rate, Sector and Year on the Exit Rate

\begin{tabular}{|c|c|c|}
\hline & Coef. & t-value \\
\hline Entry rate & $0.21 *$ & 2.37 \\
\hline \multicolumn{3}{|l|}{ Sector } \\
\hline Principal building & 0.00 & -0.57 \\
\hline Manufacturing & -0.01 & -1.59 \\
\hline Private services & $0.02 * *$ & 2.71 \\
\hline Public services & -0.02 & -1.90 \\
\hline \multicolumn{3}{|l|}{ Year } \\
\hline 2006 & -0.00 & -0.88 \\
\hline 2007 & 0.00 & 0.87 \\
\hline 2008 (reference) & & \\
\hline Constant & $0.11^{* * *}$ & 8.80 \\
\hline$R^{2}$ & \multirow{2}{*}{\multicolumn{2}{|c|}{$\begin{array}{l}0.45 \\
210\end{array}$}} \\
\hline $\mathrm{N}$ observations & & \\
\hline
\end{tabular}

* Significant at the level $P=0.05$; ** $P=0.01$; ** $P=0.001$ (robust standard errors).

have to cope with higher exit rates. Our estimation suggests that an increase of 1 percentage point in inflows is associated with a rise of 0.2 percentage point in outflows. A period of very successful recruitment thus tends to go along with higher outflows. For lethargic union locals, this finding implies that a longer period of sluggish recruitment and falling inflows may actually lead to declining outflow rates, because membership is more and more dominated by very stable long-term members, whereas unstable recent recruits become rare and rarer.

Despite our insistence that union success is primarily a function of recruitment, this result suggests that the development of a specific retention policy among recent affiliates is crucial for strongly growing union locals in order to limit the revolving door effect. Moreover, in order to achieve high entry rates over several years in a row, union locals need to constantly run recruitment campaigns which put union staff under permanent stress. This may result in burn-out and high rotation among union staff. Accordingly, ambitious goals in terms of entry rates come at a cost and may not be sustainable over a longer period. Beyond a threshold of 10-12 per cent of new yearly entries, it may be more costly to further increase inflows than to reduce outflows. Accordingly, the most successful union locals combine high entry rates with average exit rates - a combination that is only possible if the affiliation of the (annually very frequent) new members is stabilized in the first few years of their membership.

This leads us to our third issue: Can we trace membership growth and decline to tangible differences in union strategy on the sectoral and regional level? The sector organizing private services within Unia is the result of a union start-up of the mid-1990s, when the then two largest unions of Switzerland that were later to merge into Unia - the manufacturing union $S M U V$ and the building union $G B I$ - decided to jointly extend their 
organization into retail trade, hotels and restaurants. This joint venture brought together the union leaders most strongly interested in union renewal, who took up the challenge of sketching out an organizational strategy over several years (Oesch 2011: 93-4). Since this unionization effort in private services had started out from scratch less than 15 years ago, the emphasis on permanent recruitment efforts still forms part of the sector's organizational culture today - a fact reflected by high inflows in union locals organizing private services.

Likewise, the very low entry rates in manufacturing — for long the flagship of Swiss unionism - can be attributed to actions unions took and, above all, failed to take. The sharp recession of the early 1990s led to profound restructuring of Switzerland's industry. Downsizing, technological progress and upskilling reduced the size of unions' traditional blue collar clientele and eroded, at the same time, unions' long-established recruitment model in manufacturing. Notably in the engineering industry, unions had traditionally depended on works councillors and Vertrauensleute (union confidants) to recruit new members, comparable to IG Metall in Germany (Windolf and Haas 1989: 155). However, in the wake of production automation and educational upgrading, seats on works councils were increasingly taken by whitecollar employees who showed less allegiance to unions. Thus, this recruitment channel began to dry out. In the absence of new recruitment strategies, union efforts in manufacturing, particularly in engineering, gradually narrowed down to the mere administration of the status quo. The absence of a shift in resources towards organizing and recruitment officers hampered the generational renewal of union staff and resulted in very low entry rates.

An objection to our argument linking low entry rates in manufacturing to the lack of a sector strategy is that low inflows in manufacturing may be due to the sector's adverse labour market environment, notably de-industrialization and declining employment. This objection seems unfounded for two reasons. First, over the period under study 2006-2008, industrial production boomed in Switzerland and employment expanded more in manufacturing (by annually 1.3 per cent) than in the principal and secondary parts of building $(-0.6$ per cent $)$ or private consumer services $(-0.05$ per cent). In terms of job growth, manufacturing was only outpaced by public services (1.8 per cent). Second, union locals with a cohesive team and a clear shift in priority towards recruitment such as Unia manufacturing in Ticino did make strong headway among industrial workers, thereby proving that successful organizing in manufacturing was possible: the union local 'manufacturing in Ticino' increased its membership by annually 4.4 per cent between 2006 and 2008 (mean entry rate: 13.7 per cent, mean exit rate: 9.3 per cent).

\section{Conclusion}

This study has enquired into the determinants of growth and decline in union membership. Unlike the bulk of research that examines union density at the 
macro-level of country institutions or the micro-level of individual affiliation, our analysis is set at the meso-level of the union local - the place where members are actually recruited and retained. In order to get a better understanding of union locals' growth and decline, we have tried to unearth the gross flows hiding below the net change in membership. This analysis has produced three main findings.

First, gross flows in union membership are much larger than the resulting net changes. The public-sector union vpod registers annual in- and outflows of about 9-10 per cent of its membership, whereas the annual entry and exit rates of the private-sector union Unia are somewhat higher at 12-13 per cent. The literature suggests that membership turnover of around 10 per cent per year is a surprisingly constant feature of West European unions.

Second, union growth and decline seems primarily determined by inflows. Thriving union locals differ from languishing ones with respect to their entry rates, whereas exit rates are more stable and follow, to some extent, entry rates: Union locals with higher inflows have a larger share of new - and hence unstable - members and thus also tend to have higher outflows.

Third, we observe large variance in union locals' in- and outflows that is neither accounted for by employment evolution nor by the demographic composition of the recruitment area. In contrast, sector and region differences - which, as we argue, mainly translate differences in union organization and strategy - strongly affect inflows and outflows. This suggests that decisions and actions taken by unions have an influence on membership above and beyond the labour market cycle and the institutional setting.

In sum, our findings indicate that union growth and decline cannot be usefully explained with the sole reference to institutions and economic conditions. Actors and their strategic choices are central to the understanding of unions' divergent trajectories in terms of membership. The policy implication of this finding is straightforward: the key to union growth resides in larger and better targeted recruitment efforts, whereas the membership potential of retention policies - although by no means irrelevant — seems more limited. It is only once higher entry rates have been achieved that outflows become an issue. As higher inflows go along with many new and thus instable recruits, limiting outflows in times of successful recruitment campaigns may demand a special effort by union locals. Quite generally, the successful shift in union practice from servicing existing members towards recruiting new members depends upon union locals' capacity to reorient their organizational structure and culture towards organizing and constant recruitment - a reorientation that may prove excessively difficult for many union locals.

Final version accepted on 28 February 2011.

\section{Acknowledgements}

Andreas Rieger, Tschoff Löw and Stefan Giger generously provided the data and helped with the analysis. Earlier versions of this paper were presented at 
the Equalsoc Workshop 'The Demise of Collective Organization in Europe' in Amsterdam (24 July 2009) and the Unia Regio-Conference in Berne (28 September 2009). Particularly helpful were comments received from Alex Bryson, Luis Ortiz, Jelle Visser, two anonymous reviewers and the editor Christopher L. Erickson.

\section{Notes}

1. Interestingly, the two British studies find the most important organization-linked reason for leaving a union to be: 'representatives did not/did hardly ever contact me' (Waddington 2006: 26; Waddington and Kerr 1999: 192).

2. vpod stands for Verband des Personals offentlicher Dienste (the Union of the Public Services Personnel).

3. Note that not all member groups of Unia and vpod could be attributed to a union local. In Unia, some members were classified in 2006 and 2007 as belonging to a non-identified sector. In vpod, a few member groups (such as e.g. air traffic workers) are not affiliated to any union local. Accordingly, these members were excluded from the analyses based on union locals. For this reason, results based on union locals (Table 2) do not exactly match results based on total membership figures (Table 1).

4. On 1 October 2009, membership figures were 47,000 in the principal building trades (masons), 45,300 in the secondary building trades (electricians, plumbers, plasterers, carpenters), 47,700 for manufacturing (engineering, watch-making, pharma industry), 39,600 for private services (retail trade, hotels and restaurants) and 35,000 for public services (health care, education, public administration and transports).

5. These tabulations are available from the author.

\section{References}

Baccaro, L., Hamann, K. and Turner, L. (2003). 'The politics of labour movement revitalization: the need for a revitalized perspective'. European Journal of Industrial Relations, 9 (1): 119-33.

Breen, R. (2005). 'Explaining cross-national variation in youth unemployment'. European Sociological Review, 21 (2): 125-34.

Checchi, D. and Visser, J. (2005). 'Pattern persistence in European Trade Union Density. A longitudinal analysis 1950-1996'. European Sociological Review, 21: $1-21$.

Elias, P. (1996). 'Growth and decline in trade union membership in Great Britain: evidence from work histories'. In D. Gallie, R. Penn and M. Rose (eds.), Trade Unionism in Recession. Oxford: Oxford University Press, pp. 175-215.

Freeman, R. (1988). 'Contraction and expansion: the divergence of private sector and public sector unionism in the United States'. Journal of Economic Perspectives, 2 (2): 63-88.

Frege, C. and Kelly, J. (2004). 'Union strategies in comparative context'. In C. Frege and J. Kelly (eds.), Varieties of Unionism: Strategies for Union Revitalization in a Globalizing Economy. Oxford: Oxford University Press, pp. 31-44. 
Gallie, D. (1996). 'Trade union allegiance and decline in British urban labour markets'. In D. Gallie, R. Penn and M. Rose (eds.), Trade Unionism in Recession. Oxford: Oxford University Press, pp. 140-74.

Goldstein, J. (1952). The Government of British Trade Unions. A Study of Apathy and the Democratic Process in the Transport and General Workers' Union. London: George Allen and Unwin.

Hancké, B. (1993). 'Trade union membership in Europe, 1960-1990: rediscovering local unions'. British Journal of Industrial Relations, 31 (4): 593-613.

Jódar, P., Alós, R. and Vidal, S. (2009). 'Por qué los afiliados al sindicato se dan de baja. Un estudio de la desafiliación a partir de CCOO de Cataluña'. Sociología del Trabajo, 65: 31-52.

Kelly, J. and Heery, E. (1989). 'Full-time officers and trade union recruitment'. British Journal of Industrial Relations, 27 (2): 196-213.

Kitschelt, H. (1994). The Transformation of European Social Democracy. Cambridge: Cambridge University Press.

Mach, A. and Oesch, D. (2003). 'Collective bargaining between decentralization and stability: a sectoral model explaining the Swiss experience during the 1990s'. Industrielle Beziehungen, 10 (1): 160-82.

Milkman, R. and Voss, K. (2004). Rebuilding Labor: Organizing and Organizers in the New Union Movement. Ithaca, NY: ILR Press.

Oesch, D. (2011). 'Swiss trade unions and industrial relations after 1990: a history of decline and renewal'. In C. Trampusch and A. Mach (eds.), Switzerland in Europe. Continuity and Change in the Swiss Political Economy. London: Routledge, pp. 82-102.

Peetz, D. (1998). Unions in a Contrary World: The Future of the Australian Trade Union Movement. Melbourne: Cambridge University Press.

Scharpf, F. (1991). Crisis and Choice in European Social Democracy. Ithaca, NY: Cornell University Press.

Schnabel, C. (2003). 'Determinants of trade union membership.' In J. Addison and C. Schnabel (eds.), International Handbook of Trade Unions. Cheltenham: Edward Elgar, pp. 13-43.

- and Wagner, J. (2005). 'Determinants of trade union membership in West Germany: evidence from micro data, 1980-2000'. Socio-Economic Review, 3 (1): $1-24$.

Towers, B. (1997). The Representation Gap: Change and Reform in the British and American Workplace. Oxford: Oxford University Press.

Undy, R., Ellis, V., McCarthy, W. and Halmos, A. (1981). Change in Trade Unions: The Development of UK Unions since 1960. London: Hutchinson.

Van Ours, J.-C. (1991). Union Growth in the Netherlands 1961-1989, Research Memorandum 1991-33, Faculteit Der Economische Wetenschappen En Econometrie. Free University of Amsterdam.

Vaona, A. (2008). 'The duration of union membership in Italy: a research note'. Industrial Relations, 47 (2): 260-5.

Visser, J. (2002). 'Why fewer workers join unions in Europe: a social custom explanation of membership trends'. British Journal of Industrial Relations, 40 (3): 403-30.

Waddington, J. (2006). 'Why do members leave? The importance of retention to trade union growth'. Labor Studies Journal, 31 (3): 15-38.

— and Kerr, A. (1999). 'Trying to stem the flow: union membership turnover in the public sector'. Industrial Relations Journal, 30 (3): 184-96. 
and Whitston, C. (1997). 'Why do people join unions in a period of membership decline?' British Journal of Industrial Relations, 35 (4): 515-46.

Western, B. (1995). 'A comparative study of working-class disorganization: union decline in eighteen advanced capitalist countries'. American Sociological Review, 60 (2): 179-201.

Windolf, P. and Haas, J. (1989). 'Who joins the union? Determinants of trade union membership in West Germany 1976-1984'. European Sociological Review, 5 (2): 147-65.

\section{Appendix}

TABLE A1

Descriptive Statistics of Variables, Measures and Data Sources

\begin{tabular}{|c|c|c|c|}
\hline Variable & Mean & s.d. & Source \\
\hline Membership in union locals & 2856 & 1650 & Register data, Unia and vpod \\
\hline $\begin{array}{l}\text { Annual entry of new members into } \\
\text { union locals }\end{array}$ & 334.2 & 238.6 & Register data, Unia and vpod \\
\hline $\begin{array}{l}\text { Annual exit of members from union } \\
\text { locals }\end{array}$ & 354.1 & 215.9 & Register data, Unia and vpod \\
\hline $\begin{array}{l}\text { Annual change in employment in } \\
\text { locals' organizational area }\end{array}$ & 0.003 & 0.085 & Swiss Labour Force Survey \\
\hline $\begin{array}{l}\text { Annual change in unemployment in } \\
\text { locals' organizational area (in } \\
\text { percentage points) }\end{array}$ & -0.001 & 0.023 & Swiss Labour Force Survey \\
\hline $\begin{array}{l}\text { Unemployment rate in locals' } \\
\text { organizational area }\end{array}$ & 0.035 & 0.024 & Swiss Labour Force Survey \\
\hline $\begin{array}{l}\text { Union density in locals' } \\
\text { organizational area (union } \\
\text { membership / employment in } \\
\text { locals' area) }\end{array}$ & 0.118 & 0.117 & $\begin{array}{l}\text { Register data of Unia and vpod / } \\
\text { Swiss Labour Force Survey }\end{array}$ \\
\hline $\begin{array}{l}\text { Average job tenure in years in } \\
\text { locals' organizational area }\end{array}$ & 9.847 & 1.334 & Swiss Labour Force Survey \\
\hline $\begin{array}{l}\text { Share of women in locals' } \\
\text { organizational area }\end{array}$ & 0.350 & 0.221 & Swiss Labour Force Survey \\
\hline $\begin{array}{l}\text { Share of foreigners in locals' } \\
\text { organizational area }\end{array}$ & 0.281 & 0.114 & Swiss Labour Force Survey \\
\hline
\end{tabular}

Number of observations: 210 union locals. 